\title{
The Analysis of Working Capital Financing Sources (A Study on Large Red Chili Farmers in Sempu District, Banyuwangi Regency)
}

\author{
Isti Fadah, Muhammad Abdul Gofur \\ Economic Faculty University of Jember, Indonesia \\ istitatuk@yahoo.co.id
}

\begin{abstract}
Large red chili farming is a farming that has an important role in Indonesian economic development. The appropriate selection of working capital financing sources will be able to maximize the business profit for farmers. Therefore, it is important to carry out an effort in order to increase the profit and to minimize the risk of loss. The purpose of this article is to find out the working capital financing sources of large red chili farmers based on their perspectives. The type of research applied is descriptive qualitative. The selection of the informants is conducted by using purposive snowball method. The data analysis method consists of four steps: data collection, data reduction, data presentation, and conclusion. The study concludes that most of large red chili farmers in Sempu use a mixed working capital financing sources. They combine self-financed working capital with working capital obtained from middlemen. Meanwhile, the alternative sources are obtained from cooperatives and other non-formal funding sources.
\end{abstract}

Keywords: Working capital financing, working capital sources, large red chili farmers

\section{Introduction}

Indonesia is well-known as an agricultural country. It means that the agricultural sector plays a role in the development of the national economy. Briefly, the role of the sector is reflected through its contribution in the national Gross Domestic Product (GDP) establishment, employment extension, agricultural products export and other benefits given to the country in fulfilling the food supply. The agricultural sector in Indonesia includes the food crop subsector, horticulture, fishery subsector, livestock subsector and forestry subsector. One of agriculture subsectors, namely horticulture, is a potentially growing subsector in Indonesia that can also be exported overseas. Java is the largest horticultural producer in Indonesia, especially East Java. One of the regency contributing in meeting the needs of horticulture in the East Java province is Banyuwangi. Geographically, Banyuwangi is a fertile area and has a great potential in improving the development of agricultural products. Almost all agricultural commodities, especially food crop and horticulture can grow and thrive. Supported by the abundant natural resources and high market demands, horticulture becomes a high-valued product, and horticulture business becomes a source of income for farmers and other businesses from small to large scales in most of areas in Banyuwangi. Not surprisingly, due to the contribution, Banyuwangi has often become the barometer of the horticultural development in provincial and national level (http://www.banyuwangikab.go.id/page/bda/pertani an.html).

The data taken from the Department of Agriculture, Forestry and Plantation in Banyuwangi shows that in 2012, chili pepper became the greatest commodity with 2,787 ha harvest area and $18,909.80$ tons production rate. The second largest commodity is large red chili with 1180 ha harvest area and 10,877.20 tons production rate. Meanwhile, radish became the smallest commodity with 4 ha harvest area and production rate that reached 32 tons. Based on the data, chili is still the reliable commodity for farmers in Banyuwangi (http: // www. Bpskabupatenbanyuwangi.com). Large red chili is one of horticultural crops often grown by farmers. Chili is also one among many agricultural commodities that become the major concern. This is because chili is a leading commodity that has economic value, and is largely cultivated in Indonesia. Red chili is widely used as a raw material in processing industries (pharmaceuticals, food and cosmetics). Red chili is also required for export purposes. Indonesia exports it in the form of fresh red chili and powder. In the international level, Indonesian chili production reaches 1,332,360 tons per year and it is still a level below Turkey that produce 1,986,700 tons per year, Mexico that produce 2,335,560 tons per year and China whose 
total production amounts to $13,189,303$ tons per year. Based on that fact, farmers in Banyuwangi are interested to plant large red chili as their farming and business opportunity.

In general, most of large red chili farmers in Banyuwangi are small-sacle farmers who have farming land area of less than 1 hectare. The main problem that normally happens to small farmers is the lack of working capital for their farming activities. Working capital, both funds and producing infrastructure are highly influential to the process of agricultural productivity, especially for farmers who do not own working capital. In terms of working capital, chili farming requires a large number of working capitals. Economic principle applies here. That means a greater working capital, will not only generate a greater income, in accordance with the issued working capital, but also face a higher risk in running a farm. According to Kadarsan (1992: 4), agribusiness company fund has a very important role in the economy as a whole. Agribusiness fund will be related to the farmers' ability in the provision of working capital, the use of working capital, and the supervision of the use of working capital. According to Daniel (2002: 56), the soil is a key factor in agricultural business. The level of the business is also determined by the extent of land under cultivation. The production process can run smoothly and profitably if other factors can be overcome. Working capital adequacy affects the accuracy in the use of income, while lack of working capital leads to lower accepted results.

Ahmad (1997: 6) states that the size of working capital needed by a company is strongly influenced by the frequency of the company's activities. However, one thing that should be taken into account is that the size of working capital and the results of productivity must always be in balance. If the working capital is too small, the productivity will not run, and vice versa, if the working capital is too much then it will be inefficient. The definition proves that working capital is the most important component in agribusiness financing, particularly for large red chili farming. Sufficient working capital and good management will yield maximum profit. Working capital will be influential in a business operation from the beginning to end. Working capital is needed in the operational activities, not only in manufacturing sector but also in agricultural sector. For that reason, working capital is essential to all business sectors. Not only the working capital factor is to be considered, but other factors playing a role outside the business also need to be taken into to maximize the profits of farming. Natural factors are other factors that cause uncertain benefits for farmers in every season. This study was conducted to analyze the working capital of large red chili farmers, so it can be used as an evaluation for farmers and also can be used as a consideration for the selection and investment decision for the next season.

\section{Methodology}

The Study Design: This study is a descriptive qualitative research conducted to figure out a reality based on a phenomenon that occurs by using the perspectives of all parties involved either from the inside to outside or vice versa from the outside to inside (Jonker, 2011: 71). The study was conducted in Sempu district, Banyuwangi where the objects of research, which are the large red chili farmers, live.

The Types and Sources of Data: The data used in the study are primary and secondary data. The primary data is obtained from direct and in-depth interviews about the sources of working capital and the impacts on large red chili farmers in Sempu, Banyuwangi. The secondary data in the study is the general overview of Sempu where the large red chili farmers that become the informants of this study settle.

The Social Situation and Informants: This study was applied to large red chili farmers. Large red chili farmers are people who farm large red chili in their own or rented land. The object of this study is the large red chili farmers did the farming in 2013 and 2014. The purpose of the object selection is to obtain a variety of information and to describe each state of the growing season. The key informants in this study were selected based on purposive snowball sampling. Meanwhile, the explanation and the informant criteria are as follows:

- Large red chili farmers

- Inhabitants of Sempu district in Banyuwangi

- Farming in the central area or at least producing large red chili

- Having farmed large red chili farming for more than 2 years or done more than 2 times planting between 2013 and 2014. 
The Data Analysis Methods: This study is a qualitative research. The data analysis in a qualitative research is carried out during the time and after a certain period of time the data collecting takes place (Sugiyono, 2014: 91). Based on Miles and Huberman's model, the steps of data analysis in this study are conducted within four stages, namely data collection, data reduction, data presentation, and conclusion.

\section{Result}

The Definition of Working capital: All informants have given their opinions on the meaning of working capital in accordance with the informants' perceptions as large red chili farmers. Based on the result of interviews with the informants, it is concluded that working capital is a working capital that is used by farmers to finance the large red chili cultivation from the early planting time to the harvest time. According to some informants working capital is also defined as money and land.

The Working capital Funding Sources: The research result empirically shows that the working capital used by the informants comes from their own working capital, middlemen, or cooperatives. Most informants tend to combine and use more than one working capital funding sources. The models of sources combination used by red chili farmers in Sempu, Banyuwangi vary in number. It can be observed from the results of interviews about the combination of working capital resources used by farmers. As it is stated by the informants, it is considered that the most beneficial combination model of working capital funding sources for farmers is the combination between self-working capital and working capital gained from outside sources namely cooperatives or middlemen. However, most informants tend to combine their own working capital with the one from middlemen more often.

The Alternative Working capital Financing Sources: The alternative working capital funding sources chosen by the informants are various, ranging from formal sources like banks and cooperatives to informal sources, such as neighbors or middlemen. All the alternative sources selected by the informants are considered beneficial for farmers, and middleman is the alternative source that the informants tend to choose the most.

The Positive Impacts of Working capital Financing Sources: The interview results indicate that the positive impacts obtained by the farmers in choosing the appropriate working capital funding sources vary according to the selected sources. The positive impact derived from self-funding source is the quick fulfillment of working capital, without any monthly load/charge, and the fully-advantageous gain. The positive impact for the farmers offered by formal institutions (cooperatives) is the rapid process in obtaining working capital fund without any complicated administration affairs, beside the compliance on individual confidentiality and the tolerance on late-payment interest charges. Meanwhile, most farmers who received working capital from non-formal institutions (middleman) gain positive impacts, such as the long-term period of loan payment, the absence of collateral, and the share of risk.

The Negative Impacts of Working capital Financing Sources: The informants have also given their opinions on the negative impacts of each working capital financing source for large red chili farmers. According to the informants, the negative impact of self-funding source for the farmers is that they will have to bear losses on their own. Formal institutions such as cooperatives or banks will charge interest expenses that must be paid in a certain frame time. Meanwhile, the negative impact of informal sources like middlemen is the low selling price as a consequence under an unwritten agreement. It is concluded that working capital funding sources selected by the chili farmers offer both advantages and disadvantages for them.

\section{Discussion}

The Working capital Funding Sources for Large red chili Farmers: Based on the interviews with 15 informants, it is noted that the working capital funding sources selected by large red chili farmers in Sempu are diverse. The results indicate that all informants tend to use different sources, ranging from self-funding sources, cooperatives and middlemen. According to some informants, the farmers use self-funded working capital because there will not be any reduction on selling price, monthly loan-interest expense and burden of payment on losses. However, unconsciously, farmers do not know that the use of self-funding working capital 
will also lead to invisible costs, namely opportunity costs. According to Brigham and Houston (2013: 96), opportunity cost is an expense as the result of option to use the best asset, or an expense that causes the highest amount of returns unable to obtain since the fund is invested to a specific project only. Another opportunity that can be obtained by farmers besides investing their fund on chili farming is the opportunity to invest in bank deposits. The amount of interest on bank deposits is also a consideration for farmers in determining investment. Based on the interview results, several informants stated that a few farmers use fund obtained from formal institutions such as cooperatives. The farmers prefer cooperatives because the administration affairs are not as complicated as those in banks. The fund can be obtained faster and bigger in number depending on the warranty proposed by the farmers. The risk of this funding source is that farmers bear the cost of the interest every month in any conditions, including crop failure that the farmers will possibly face. For that reason, only a few farmers who are interested to choose working capital offered by formal institutions such as cooperatives or banks. Farmers who possess securities as collateral will have the chance to get the working capital from cooperatives much easier, but small farmers who do not have sufficient assets as warranty to propose loans from cooperatives prefer working capital gained from nonformal institutions such as middlemen.

Most informants stated that informal working capital funding sources such as middlemen are more preferable due to the flexibility of getting working capital without any collateral. It is in line with Nurmala (2012: 129) who states that the reasons why farmers rely more on loans from formal institutions are:

- It is easy to apply and offers instant services.

- The administration is not too much convoluted because only through an authorized receipt the farmers will be able to receive the fund.

- The number of fund is not strictly limited and depends on the farmers' needs.

- There is not any specified time limit or office hours.

- Only stated trustworthy or unripe crops are put as collateral.

Despite the higher interest rates compared to that offered by formal institutions, the farmers prefer to use informal institutions. The interest cost charged is in the form of sale price variance in which becomes a form of fees charged to the farmers who are indebted to middlemen. The amount of sale price variance ranges between IDR250 up to IDR1,000 per kilogram or more, depending on the price of chili at current time. The higher the sale price increases in the season, the greater the variance or price cut will be charged to the farmers and vice versa a lower sale price will lead to smaller sale price cut or reduction. The amount of sale price variance also depends on the amount of loan proposed by farmers. A bigger proposed loan will lead to a bigger sale price cut given to the farmers. Erratic weather factor and unpredictable yield make farmers extremely careful in choosing a funding source of working capital. Most of the informants who are not willing to take big risks tend to choose working capital from middlemen because middlemen dare to bear the risk of crop failure that the farmers will probably face by offering the opportunity to replant the next season as warranty. However, the middlemen also propose certain conditions to farmers who want to borrow working capital. Although not legally written, these requirements are binding. The conditions proposed by the middlemen consist of: 1 . Crops have to be paid to middlemen, 2 . Farmers have to be willing to get a sale price cut charged to each kilogram of chilies they yield, 3. Farmers will get a penalty in the form of termination of cooperation and a force on debt payment or rejection on the next loan proposal, if they violate the terms agreed that is to sell the chilies to other traders. Somehow, the terms and conditions proposed by middleman are burdensome because farmers cannot sell their harvests to other traders who potentially offer promising higher price, so that farmers cannot maximize the benefits. However, according the informants, the farmers do not mind the conditions proposed by middleman. In fact there is one informant who deliberately borrows working capital from middlemen despite having sufficient self-working capital to share the losses on crop failure that is probably faced.

The forms of working capital obtained by the farmers from middlemen can be cash or goods such as fertilizer, mulch, chili seeds, or farming chemicals that are considered equal to the amount of cash proposed. The amount of working capital offered by middleman to the large red chili farmers is appropriate to the farmers' needs. Although some farmers obtain funding from middlemen, they also combine it with self-funding working capital or working capital offered by cooperatives. Based on the facts, the majority of informants tend to combine the funding sources that are considered beneficial for them. The statement was supported by 
Hornet and Wachowicz (1992: 251) who imply that the selection of the best combination of short-term funding sources (working capital) depends on considerations of cost, time availability, flexibility and the degree to which the company's assets is charged under lawsuits. The beneficial combination for the majority of informants is the combination of self-working capital and working capital gained from middlemen, with composition, the amount of working capital gained from middlemen is bigger than or equal to self-working capital. This contrasts with Utami (2012) and Sholihah (2013) who states that the use self-working capital is more beneficial than the use of external source working capital. Judging from the composition of working capital sources combination applied by the farmers, indirectly, they also understand and apply the theory of bankruptcy costs (financial distress). According Brealey, Myers and Marcus (2008: 14), the more the companies owe, the higher the chance of payment failure they bear and therefore the greater the expected value of associated costs they expense. Along with the use of $100 \%$ loan, the cost of debt or financial distress also has to be taken into account. It is the cost of bankruptcy that causes farmers unable to obtain optimal benefit from the use of $100 \%$ loans from middlemen. Therefore, most farmers do not depend entirely on working capital loan given by middlemen. This is also supported by Kadarsan's statement. According Kadarsan (1992: 61), working capital loan needs limitations, because the more loans taken from one single source will lead the greater the costs, both economic and non-economic costs.

Funds or working capital gained from selected sources may run out before the harvest time, so farmers need to have some alternative options to meet their working capital financing. From interviews, most of the informants prefer to propose more additional working capital to middleman because they are fully prepared to fulfill the farmers' needs. Other informants prefer to borrow from neighbors or cooperatives. In the case of working capital shortage, some informants prefer to borrow it from the banks. According Pasaribu (2012: 87), bank is one of financial institutions that can be used as a source of funding, including financing micro, small, medium enterprises. The working capital offered by banks is greater than the loan offered by cooperatives. Another advantage offered by banks is the interest rate that is relatively low compared to the one offered by cooperatives. However, only farmers with large lands dare to risk in obtaining funding from banks. The time duration needed by large red chili farming from planting to harvest is approximately 4-5 months. Profitable crops may help the farmers to return the operational working capital used, as well as the loan obtained either from formal and informal institutions. The farmers' income is unpredictable in every season. According to the informants, the farmers prefer to use self-funded working capital and working capital from informal institutions such as middleman. The option is selected in case of crop failure to reduce the high risks for the sustainability of farming the next planting season.

Based on the discussion above, some implications are proposed. The large red chili farming actors in Sempu, Banyuwangi should not be fully depended on working capital offered by middlemen, in order to maximize the profits. Furthermore, the financial institutions are expected to reach more rural farming actors to use financial products in the form of agribusiness working capital loans, because this will activate the role of financial institutions towards the perpetrators of chili farming in meeting the needs of working capital. The middlemen are expected to give a transparency on chili sale prices, so that farmers will not face any losses. Then to the government, their supports are needed to achieve the welfare of chili farmers either who have just started or have run for a long time by providing them easy accesses to working capital funding sources, beside extending special working capital loans in agriculture without burdensome requirements for farmers to increase their working capital base through both financial and non-financial institutions.

\section{Conclusion}

The big chili farmers in Sempu, Banyuwangi use combined working capital funding sources that are selffunding source and external funding sources, namely middlemen. Meanwhile, the alternative working capital funding sources that they tend to choose are cooperatives and non-formal funding sources.

\section{References}

Badan Pusat Statistik Kabupaten Banyuwangi. (2012). Luas Panen dan Produksi Tanaman Sayuran Menurut Jenis Komoditas Tahun 2012. Dipublikasikan. Laporan Penelitian. http://wwww.bpskabupaten banyuwangi.com/index.php.html [diakses 16 April 2014]. 
Brealey, R. A., Myers, S. C. \& Marcus, A. J. (2008). Dasar-Dasar Manajemen Keuangan Perusahaan Jilid 2. Jakarta: Erlangga.

Brigham, E. F. \& Houston, J. F. (2013). Dasar-dasar Manajemen Keuangan Edisi 11 jilid 2. Jakarta: Salemba Empat.

Dinas Pertanian, Kehutanan dan Perkebunan. Kabupaten Banyuwangi, Barometer Perkembangan Hortikultura Skala $\quad$ Nasional. $\quad$ Dipublikasikan. Artikel. http://www.banyuwangikab.go.id/page/bda/pertanian.html [diakses 13 Maret 2014]

Jonker, J. (2011). Metodologi Penelitian. Jakarta: Salemba Empat

Kadarsan, H. W. (1992). Keuangan Pertanian dan Pembiayaan Perusahaan Agribisnis. Jakarta: PT Gramedia Pustaka.

Ahmad, K. (1997). Dasar-dasar Manajemen Modal Kerja. Jakarta: Rineka Cipta.

Daniel, M. (2002). Pengantar Ekonomi Pertaniaan. Jakarta. Bumi Aksara

Nurmala, T. (2012). Pengantar Ilmu Pertanian. Yogyakarta: Graha Ilmu.

Pasaribu, A. M. (2012). Perencanaan \& Evaluasi Proyek Agribisnis Konsep dan Aplikasi. Yogyakarta: Lily Publisher.

Sholihah, I. F. (2013). Analisis Modal Kerja Petani Tembakau Desa Sumber Pinang Kabupaten Jember. Skripsi. Universitas Jember.

Sugiyono. (2014). Memahami Penelitian Kualitatif. Bandung: Alfabeta.

Utami, I. A. T. (2012). Analisis Sumber dan Penggunaan Modal Kerja pada Pegawai Negeri Balai Kota Samarinda. Jurnal Eksis, 8(2). 